\title{
The role of higher education in preparing youth to manage a sustainable future workplace
}

\author{
Mona BETOUR EL ZOGHBI
}

Independent Sustainability Consultant, Beirut, Lebanon

Wim LAMBRECHTS

Open University of the Netherlands, Heerlen, the Netherlands

\begin{abstract}
:
Aim: This paper aims to highlight the different forms, levels and pathways of engagement with climate change and sustainability of young people living in different contexts of vulnerability and adaptability. It explores different perspectives and viewpoints of youth regarding complex and uncertain issues related to climate change and sustainability as well as their future role on the workplace.
\end{abstract}

Research Methods: The critical interpretivist study was conducted in the Netherlands and South Africa, and participants were undergraduate and postgraduate university students from diverse sociodemographic and academic backgrounds in the two countries. The study applied various methods of data collection including focus groups, interviews, policy document reviews as well as participantobservation at several youth and environmental events and forums.

Conclusions/Findings: Key findings highlight the importance of building resilience and empowering academic and civic platforms that enhance young people's competences to manage sustainabilityoriented lifestyles and workplaces through critical, creative, and collaborative processes.

Keywords: youth education, engagement, empowerment, climate change, sustainability.

JEL: I20, I23, J24, Q01, Q56

Correspondence address: Mona BETOUR El ZOGHBI, Independent Sustainability Consultant, Beirut, Lebanon. E-mail: monazoghbi@gmail.com (Mona BETOUR El ZOGHBI), wim.lambrechts@ou.nl (Wim LAMBRECHTS)

Received: 12.03.2018, Revised: 05.07.2019, Accepted: 05.07.2019

doi: http://dx.doi.org/10.29015/cerem.692 


\section{Mona BETOUR EL ZOGHBI, Wim LAMBRECHTS}

\section{Introduction}

Young people in (higher) education constitute the key (business) leaders, decision-makers and citizens of future society. University and college students therefore need to develop the skills and competences to live and work in an increasingly globalized world, climate-threatened future, and sustainability-oriented economy (Nyoni 2009). Coping with the growing complexity and uncertainty of global sustainability issues, often described as super wicked problems (Levin et al. 2012), requires specific skills and competences, related to systems thinking, anticipatory thinking, diversity, emotional intelligence, strategic management and action, and normative aspects (Ploum et al. 2018; Wiek et al. 2011), as well as frustration tolerance (Rieckmann 2012) and dealing with uncertainty (Tauritz 2012). In the current timeframe, often referred to as the "post-truth" age, critical and interpretational competences play an important role as well (Lambrechts, Van Petegem 2016; Lambrechts et al. 2018). Yet it can be argued that the prevailing educational system has partly contributed to widening the global climate crisis through unidirectional and individualistic worldviews which promote unsustainable values and practices (Sterling 2008). Orr (2004: 2) argues that "the ecological crisis concerns how we think and the institutions that purport to shape and refine the capacity to think." UNESCO's Decade of Education for Sustainable Development (DESD) put forward a new purpose for education to replace the traditional informational approach. The core vision of the DESD was to engage all stakeholders in critical, holistic and fore-sighted education and learning, and to encourage multistakeholder and intercultural dialogue and collaboration, promoting a pathway towards positive and sustainable societal change (Tilbury 2011).

With current transitions towards new (green, sustainable, biobased, circular) economic models and important transformations in job requirements and tasks, the role of education and learning for sustainability in empowering young people is being increasingly emphasized (Stewart 2010; Wiek et al. 2011). Today's higher education graduates will need to manage these transformations in their future lives and workplaces. According to Barnett (2000), climate change is characterized by super- 
complexity, necessitating new forms of education and learning that enable young people to influence positive changes. Other authors, like Levin et al. (2012) refer to climate change as a super wicked problem, thereby highlighting the urgency, complexity, uncertainty and inability of current authorities to define solutions. The International Labour Organization (ILO 2012) and the United Nations Department for Economic and Social Affairs (UNDESA 2010) have also emphasized the importance of addressing the current skills gap in the workforce and young graduates to enable them to adjust to major shifts in the global market towards sustainability. Young people therefore need to be empowered through knowledge, skills and competences that enable them to contribute to the consultations, decisions and actions shaping their future quality of life and career prospects.

This study seeks to enhance understanding about the ways in which Higher Education Institutions (HEIs) are mobilizing and empowering young people to manage complex and global environmental and societal challenges. The research was undertaken in the Netherlands and South Africa throughout 2011, coinciding with the International Year of Youth and the 17th Conference of the Parties (COP17) of the United Nations Framework Convention on Climate Change (UNFCCC) held in South Africa. This paper reports on one particular theme within the study findings pertaining to the educational opportunities and challenges for youth engagement with climate change and sustainability issues. The two main objectives of this paper are to:

- Identify the educational challenges and opportunities for university students in the Netherlands and South Africa to manage and lead the transition to sustainability in future workplaces.

- Generate recommendations that can inform policy and practice in key priority areas to enhance the education and learning experiences of university students in contributing to sustainability. 


\section{Mona BETOUR EL ZOGHBI, Wim LAMBRECHTS}

\section{Theoretical background}

It is generally acknowledged that higher education prepares its students for their future role in society, whether as a citizen, consumer, professional, or entrepreneur (Cortese 2003; Lambrechts et al. 2013). As an academic discipline, the field of Higher Education for Sustainable Development (HESD), also referred to as Sustainable Higher Education (SHE), the role of higher education in sustainability transition processes is often clarified by defining and conceptualizing competences (e.g. Barth et al. 2007; Rieckmann 2012; Wiek et al. 2011). Following Rychen and Salganik (2003: 43), a competence is "the ability to successfully meet complex demands in a particular context through the mobilization of psychological prerequisites (including both cognitive and non-cognitive aspects)." The competence concept therefore includes knowledge, skills, values and attitudes (Rychen, Salganik 2003; Baethge et al. 2006).

Different competence frameworks comprising individual sustainability competences have been presented (e.g. de Haan 2006; Barth et al. 2007; Rieckmann 2012; Wiek et al. 2011; Ploum 2018), yet many of these were criticized for being mere laundry lists, as well as for the lack of holistic integration of knowledge, skills, values and attitudes (Lambrechts, Van Petegem 2016; Wiek et al. 2011). In their seminal article, Wiek et al. (2011) present a framework of "sustainability research and problem-solving competence," comprising five key competences for sustainable development: systems-thinking competence, anticipatory competence, normative competence, strategic competence, and interpersonal competence. Several other competence frameworks (e.g. Rieckmann 2012, presenting twelve competences) as well as further conceptual refinements (e.g. Ploum et al. 2018, presenting six competences; Salgado Perez et al. 2018, exploring the role of intervention competence) have been presented since then.

Interestingly, as noted by Ploum et al. (2018) most of the studies regarding individual sustainability competences were conducted within the context of higher education, leaving the perspective of professionals untouched (recent contributions however do investigate these competences in the workplace, e.g. Lambrechts et al. 2019; Salgado Perez et al. 2018). Yet, as Lambrechts et al. (2018, p.563) point out, 
"the perspective of the student is often neglected within the discourse of defining competences". Studies regarding further conceptualization and integration of individual sustainability competences focused on the perspective of the university educators, more specifically professional development and empowerment of academic staff (e.g. Cebrián et al. 2015; Di Giulio, Defila 2017; Lambrechts et al. 2017; Mula et al. 2017), as well as different transdisciplinary or "real-world" educational approaches in order to better prepare students for their future role (e.g. Brundiers et al. 2010; Tejedor et al. 2018). Specifically within the context of teacher training, Cebrián and Junyent (2015) analysed student perceptions regarding competences in relation to education for sustainable development, and concluded that existing competence frameworks need thorough revision in order to "promote the awareness and development of ESD competencies amongst student teachers" (Cebrián, Junyent 2015: 2768). Certainly in times when students around the globe protest for climate (Vaughan 2019), it is important to explore the students' perspective in further conceptualizing individual sustainability competences. As Lambrechts et al. (2018: 566) state: "students show complex, layered and multi-dimensional attitudes toward sustainability."

\section{Research context and methods}

This research was conducted in the Netherlands and South Africa. The Netherlands is a developed country with a high vulnerability to climate change from sea level rise and associated risks, but has a wealth of human, financial and technical resources for adaptation and mitigation. The climate risks however require continuous management, innovation and action. Dutch young people will be the frontrunners in dealing with these challenges in their daily lives as well as in working towards solutions in their communities and jobs (Van Heeswijk 2009). In South Africa, university students are facing long-term risks from climate change as well as overlapping social and developmental stresses including widespread poverty, social and economic inequities, complex governance and institutional problems and limited access to capital (Madzwamuse 2010). Overall, such complexities overburden South 


\section{Mona BETOUR EL ZOGHBI, Wim LAMBRECHTS}

Africa's higher education graduates in particular, who will need to drive sustainability whilst managing existing socio-economic and environmental difficulties. Such contextual country differences in terms of climate change vulnerability and adaptability present valuable settings for exploring the diverse forms, opportunities and challenges for youth engagement with climate change and sustainability.

The study applies a critical interpretivist research approach. It seeks to understand young people's experiences through their own accounts and interactions in a reflective and dialogic setting. The focus is on the role of local country context (social, educational, political and institutional systems) in influencing youth opportunities and challenges for engagement with climate change and sustainability. The study methods included focus groups with youth, semi-structured interviews with young people and experts, participant-observation at various youth events, and a review of policy documents.

The study participants included Dutch and South African university students, undergraduates and post-graduates between 18 and 30 years old, both male and female. Participation in the focus groups and interviews was voluntary. In South Africa, a total of 10 focus groups were conducted with total of 117 students from more than 12 universities in different regions (including KwazuluNatal, Durban, Johannesburg, Pretoria, Grahamstown, Port Elizabeth, CapeTown). Semi-structured interviews were also held with university students from different academic fields and with key informants or experts including government officers, academic researchers and coordinators in youth or environmental organizations. The first author also attended three youth events as a participant-observer: a southern African regional media conference, a national sustainability conference, and a youth leadership forum. These events included youth participants from different regions of South Africa and ranged from university students to young professionals. In the Netherlands, a total of 8 focus groups were conducted with a total of 66 participants from more than 10 universities (including Amsterdam, the Hague, Utrecht, Rotterdam, and Wageningen). Semi-structured interviews were also conducted with Dutch university students and with key informants. Three events were attended as a participantobserver: a two-day reunion by a youth nature group; an on-campus workshop by a student sustainability committee; and a youth-run energy efficiency campaign. The 
on-campus youth event mainly targeted university students, whereas the other two events included a broader cross-section of young people from different academic and professional backgrounds. The study applied thematic analysis using an inductive analytical approach. Research ethics were maintained through ensuring privacy, confidentiality and anonymity (Willis 2007).

\section{Findings and discussion}

The study captured important findings regarding forms of engagement of young people with climate change and sustainability issues and the role of their education and learning experiences in hindering or enhancing this engagement. These findings are presented below and discussed in relation to the relevant literature.

\subsection{Lack of critical reflection and solution-based approaches in current education}

A majority of the study participants highlighted weaknesses in the current way education prepares young people to manage real-world problems such as climate change. They particularly pointed out the prevalent disconnected thinking amongst the public, which they considered to have been shaped by educational approaches that do not promote critical and systemic thinking among young learners. A Dutch focus group (FG) participant discussed such shortcomings of current education:

"When people buy a car they don't think of kids in Africa or how much energy and resources are needed. We need to see the bigger picture, realize we are all interconnected. We have to change education. Most educational programmes don't address these problems and this way of thinking. They teach small basics on environmental awareness but not the overall picture, or an understanding of a sustainability worldview. It wasn't really presented as an issue that we all have to work on." 


\section{Mona BETOUR EL ZOGHBI, Wim LAMBRECHTS}

A South African student participating in a national youth forum also highlighted the lack of space for critical and reflective thinking in current modes of schooling and education:

"Usually there is no reflection. For example in school, if environmental issues are raised, the teacher shows a picture, asks students what do they think about it; then switches off projector and that's it, back to normal class, no reflection, no discussion."

Many study participants also emphasized the need for educational reforms that incorporate more holistic thinking and integrate sustainability education and learning into various educational spaces and disciplines. For example, a Dutch FG participant discussed the need for teaching students through hands-on/practical and solutionbased learning approaches:

"Schools should do more. For me it was an important place where I got information. Not just by telling kids and giving info, but in giving them assignments, asking them to go and find out how the world works, doing research, letting them understand and look it up for themselves. Make them think about it. For example, I wrote an essay about different types of vegetarianism and looked at different arguments, it made me understand and I got convinced."

Similar insights into the need for critical thinking and problem solving skills were discussed by young participants in a study by Burandt and Barth (2010: 12) who found that "problem-orientation and the need to act and decide within complex real-life problems where multiple perspectives had to be integrated, was mentioned as the main precondition to acquiring new knowledge and skills." Universities and colleges can optimize their role as key agents of social change by comprehensively integrating education and learning for sustainability into their framework of thinking through a comprehensive approach that engages students with research, education and learning, and outreach for sustainability (Wiek et al. 2011). Matthews and Waterman (2010) indicated that skills, values, and aptitudes are advanced through "learning by doing" 
pedagogies for sustainability literacy. They emphasized that "learning by doing goes beyond the idea that core, disciplinary or technical knowledge is straightforwardly transmitted through uncomplicated processes of teaching and learning. Rather it involves hands-on activities which facilitate knowledge, skills application, and adaptation" (Matthews, Waterman 2010: 83). ESD can thus empower youth to become core stakeholders and collaborators towards a sustainable future. Yet, as pointed out by Lambrechts et al. (2018), the current "post-truth" timeframe requires a stronger framing of the individual sustainability competences within this context, e.g. by connecting to research competences and information literacy (Lambrechts and Van Petegem 2016) and critical and interpretational competences (Lambrechts et al. 2018), in order to enable students to critically reflect upon the complexity and uncertainty of sustainability issues.

\subsection{Low priority for education for sustainable development}

A widely shared theme amongst participants in both countries was the low priority given to climate change and sustainability education in their academic curricula. This is reflected in the following quotes by two participants from the Netherlands and South Africa, respectively:

"We have no university courses on the environment. In school we only get the basics, what pollution is...My main sources of knowledge or information on sustainability are climate scandals and social networks."

"It's growing but we're still leaving it at an optional level. Right now in law, we have environment law as an option, then the lecturer became pregnant. They didn't try to replace the lecturer, they scrapped the course. It's that unimportant."

Another FG participant from South Africa argued that such shortcomings in their education impeded their ability to develop skills which they considered necessary for their future jobs. 


\section{Mona BETOUR EL ZOGHBI, Wim LAMBRECHTS}

"We don't have a lot of environmental courses in our curriculum. So usually about climate change I see it accidentally on the internet; through campaigns or from television coverage of climate events or scandals... Existing school structures can't promote this knowledge. Students get no platform to expand their knowledge and skills and grow into a green economy."

The literature highlights the importance of embedding education for sustainable development (ESD) across the functions of higher education institutions. It also highlights the importance of experiential and interdisciplinary learning for enhancing the holistic and critical understanding of different academic and social disciplines for young people and preparing them for professional work (Stewart, 2010). ESD provides an opportunity for reflecting and re-orienting current ways of relating to and valuing ecosystems, utilizing resources, and understanding the inter-connections of the natural and social world.

A distinct theme expressed by some Dutch participants was the lack of depth and skills development in sustainability courses. Two FG participants shared their experiences:

"I study entrepreneurship, and am now focusing a lot on people, planet and profit and how you have to consider all these. We have business presentations from companies who want to sell the fact that they are green. But we are not really educated on what the problem really is or how to manage it."

"The sustainability course was very broad, too quantitative, not deep, - it was like children's physics. Too focused on teaching physics and technique behind it...rather than impacts of climate change, or the diplomacy behind it and how we can change countries, or the policies that need to be adopted to get sustainability."

In an interview with a policy maker on the political dimensions of sustainability education in the Netherlands, he explained that "the new government has announced 9 branches of industry for Netherlands to be leading in, such as chemistry; life sciences; bio-based economy; and the creative industry... the development agendas on 
economic reform have sustainability as an underlying principle. But at the same time they are cutting a lot of funds and investments from arts, culture, environmental studies...sure this will have an impact on how higher education manages. But anyway in Netherlands HE can decide their own programmes. So it also needs to come from there."

This reflects the institutional challenges of integrating ESD into higher education and the importance of attaining political and legislative support for sustainability education as reported in the literature (e.g. Leal Filho 2011; Lozano et al. 2013, 2015; Wals 2014). Educational change requires organizational change as well, yet different factors influence these change processes positively or negatively (Barth 2013; Disterheft et al. 2015; Hoover, Harder 2015; Verhulst, Lambrechts 2015), and the intertwined educational and organizational change poses challenges to higher education institutions (Lambrechts et al. 2015, 2017). As pointed out by Wals (2014: 8): "they are doing so amidst educational reforms towards efficiency, accountability, privatization, management and control that are not always conducive for such a reorientation."

A distinct theme expressed by many South African participants was the lack of teacher training and awareness on environmental issues such as climate change. Two FG participants stated:

"They introduced new subjects on sustainability and on corporate social responsibility but used the very same teachers that had been teaching other courses. They don't have the background and understanding or skills to teach this new material... Course didn't touch on anything new except what we all already knew. Save water, electricity... There was no real depth into what happens, the process, the outcomes, the long term issues we will have to deal with in our jobs."

"Teachers are not properly educated about issues like climate change especially those in rural and under-privileged areas. We need proper teacher education... People in the community need to learn the skills to live sustainable and efficient lives." 


\section{Mona BETOUR EL ZOGHBI, Wim LAMBRECHTS}

These insights resonate with findings in other studies exploring ESD in South Africa. For example, Moodley (2010) found that the environmental education programmes in the Gauteng province "had very little or no focus on the social and economic aspects of the environment... the practitioners sampled in the study were trained in environmental education and there appears to have been no formal training regarding education for sustainable development" (Moodley 2010: 64). Bopape (2009) similarly indicated the lack of teacher training within the South African academic context and recommended the incorporation of environmental education into teacher professional development programmes in South Africa. McKeowen and Hopkins (2010) also emphasized that educating for change requires engaging teachers in this change process, and that climate change and ESD education need to be locally and culturally appropriate.

Another distinct theme emerging from the South African data was the low priority given by students to environmental courses. Some participants indicated that this was influenced by the socio-economic context:

"The modern age is a service age, so fewer people are doing sciences. The focus is not on what's the way forward. The focus is on how we can improve budgets and what we have already... Science majors are not getting as much money as business majors. Accounting is where most people are getting paid."

"Students doing biology are pushed by their parents to do commerce - something with a real job. Most are first to get education in their households and are the main breadwinners. The family are dependent on them to get money... We need to link biology and science to business to show them possibilities."

Lotz-Sisitka (2002) indicated that environmental education in southern Africa is the key to investing in both human development as well as the protection of the environment to ensure sustainable livelihoods and safe environments. She emphasized that environmental education processes are essential, particularly in contexts where livelihoods are dependent on natural resources; hence the need for re-orienting and 
re-establishing the links between socio-cultural, economic, natural and political dimensions.

\subsection{Contribution to positive societal change}

This study captured important findings about young people's perspectives regarding opportunities for personal and professional development through their responses to the global climate change crisis. Most participants discussed these opportunities in terms of the contributions they would like to make through their professional careers in enhancing awareness in society and action on climate change and sustainability issues. A law student from a South African focus group session expressed interest in working on sustainability policies that could better serve community livelihoods:

"I hope to see more and stricter environmental laws. Perhaps as a lawyer I will play a role in bringing these laws to pass. I would like to see those communities who rely on unsustainable resources for their livelihoods successfully find alternative occupations."

Another FG participant from South Africa discussed the role of the media and art in raising public awareness on climate change:

"I'm studying drama because I think theatre is a way to educate people and bring change, to influence people... So we can use theatre to raise awareness on climate change."

Similarly, a Dutch participant in a sustainability event hoped to work in sustainable agricultural production to meet the rising challenges from climate change:

"I am studying agriculture and I now see the effect of weather changes on produce. As a future farmer, my ideal would be to produce enough food of good quality and every year to improve soil health. That would be my 


\section{Mona BETOUR EL ZOGHBI, Wim LAMBRECHTS}

contribution; my own farm to increase soil health every year. It has to be worldwide, but I'll try to do my part."

Fritze et al. (2008) discusses the fact that climate change will generate the need for a range of different jobs and careers to support people and institutions and enhance people's resilience and "galvanize creative ideas and actions in ways that transform and strengthen the resilience of and creativity of community and individuals" (Fritze et al. 2008: 9). The ILO (2012) also indicated that climate change will have an impact on labour markets through the creation of new jobs and the substitution and transformation of existing jobs. Although some jobs might disappear, new jobs will be created, for example, in the construction sector building coastal defenses and green buildings. Certain job requirements will be redefined as society shifts from fossil fuels to renewables and with an increased focus of the industrial sector on clean technologies and of the service sector on energy savings. Such insights further highlight the importance of integrating ESD into academic curricula in order to build young people's knowledge and competences to manage a transforming workplace through skills for critical and futures thinking, flexibility and adaptability, social learning, sustainable technologies and inter-disciplinary collaboration.

\subsection{Innovation in future career}

Many of the study participants undertaking environment-related studies or courses considered climate change as an opportunity for them to find jobs and to innovate within their career prospects. This viewpoint was especially prevalent amongst the South African participants, as demonstrated by the following quotes from various FG sessions:

"Climate change can be a threat to a future career or can be opportunity to study changes occurring and adaptations in different organisms. As an etiologist, climate change will have impact on my career because the ocean as an ecosystem is very sensitive to changes we are facing now." 
"It opens up job opportunities. Every company and government sector needs environmental experts, also for enterprise development... It's a young field and it's growing. Also internationally, wherever you go they will always need environmentalists, especially someone from 'Africa'."

"A lack of food and resources creates jobs for us as environmental scientists to study and find alternative ways of food production. The government would not need to invest its money in expensive technologies."

Within the particular South African context, Lotz-Sisitka (2009) emphasized that the multiplicity of social and economic stressors present valuable opportunities for education for sustainability to be integrated into higher education, thus expanding the platform for South Africa's higher education youth to learn and develop into a sustainable society and economy.

Furthermore, some participants discussed the ways in which their future jobs and careers would require competences and skills to perform well in an increasingly sustainability-oriented economy and market system. For example, a Dutch FG participant pointed out the importance of attaining the values and skills to adapt to the physical and structural changes happening in their everyday lives and for enhancing their performance in future careers.

"There are a lot of opportunities in businesses and industries. You have to know how to do things differently. So I'm here (in the sustainability leadership class) because I will need to learn these skills for my job... and it's good on the CV."

Similarly, a South African FG participant pointed out to the skills and competences that future engineers will need to acquire:

"Attitudes have to change in upcoming engineers and architectures. People in power are not really aware of these things (for example - climate change) and how to prevent them. So we as engineers, who are learning to make structures to 


\section{Mona BETOUR EL ZOGHBI, Wim LAMBRECHTS}

build houses, need to learn to do it sustainability. We should focus on structures that incorporate the environment into it instead of destroying it."

Various scholars and institutions have emphasized that the future workplace will require skills in critical and fore-sighted thinking, collaboration amongst different disciplines and innovative solutions for efficient management of scarce resources (Fahey 2012; Wiek et al. 2011). The European Commission (2009: 2) considered that skills are "the best insurance against unemployment and an important factor for personal development and active citizenship." In addition the Netherlands Environmental Assessment Agency (PBL 2011) warned that the Dutch and general European working population, is aging and expected to decline further, arguing towards more innovation, better education and a greener economy to maintain prosperity and deal with the long-term climate challenges. Yet a study on the integration of sustainability competences (Lambrechts et al. 2013) has similarly highlighted the lack of educational programs that promote competences for systems thinking, future orientation and personal action on sustainable development; hence further emphasizing the importance of revising HEI curricula to address sustainable development competences for empowering young people to manage a sustainabilityoriented future workplace.

\section{Conclusion}

In this study, the participants' discussions revealed important insights regarding the extent to which their current education and learning is equipping them with the necessary worldviews, skills and competences for a sustainability-oriented society and job market. Several participants criticized the low priority given to climate change and sustainability education in their current institutional programmes and courses, and that this impeded their ability to develop skills they consider necessary for future employment and social cohesion. The participants' perceptions of power and opportunity for personal and professional development through their jobs, and of their agency to influence the changes they envision might be diminished in the absence of adequate education and training to enhance their employability and performance. The 
study thus highlights the need for educational programmes that enhance young people's critical and reflective thinking, holistic worldviews, and collaborations with stakeholders across different disciplines.

Several key recommendations for policy and practice that address the specific set of findings from this study are identified. First, integrating educational programs in HEIs that focus on competence development for sustainable development, particularly through promoting young people's skills for social transformation including critical reflection, future thinking, creativity and innovation, and participatory and problem solving abilities. This will enable them to manage, personally and professionally, the complex real-world challenges such as climate change. Second, incorporating ESD concepts into teacher education programs and pre-service and in-service teacher training; establishing (on-line) platforms for teacher professional development, resources and teaching material on ESD; and developing ESD guidebooks for teachers and training teachers on their application in the classroom. Third, developing programs and mechanisms by the public and private sector for supporting and empowering young people with innovative ideas, solutions and community projects on sustainable development and climate change in order to encourage and enhance youth personal and collective contribution to positive societal change. At the public level, such mechanisms could entail establishing formal youth platforms and councils for meaningful youth consultation and participation in decision-making and action. At the private level, in addition to the role of HEIs, young people could also benefit from skill-enhancement programs by youth NGOs, sustainability-based internship programs by companies. Media exposure and awareness of youth initiatives on ESD and sustainability through journalist's reports, youth and sustainability event coverage, and interactive sustainability-themed television, radio and social media shows that such activities can be led and managed by youth. Such programs and mechanisms provide diverse opportunities for young people with innovative ideas and who are keen to engage with sustainability issues in their future careers to enhance their skills, networks, experiences, competences, as well as contributions for sustainability. Fourth, devising formal and informal competence development schemes, especially in developing countries, that can fill the current skills gaps across 


\section{Mona BETOUR EL ZOGHBI, Wim LAMBRECHTS}

diverse youth and adult stakeholders and ensure social and gender equity in youth inclusion in the transition to a green economy.

Future research should explore the dynamics and possibilities for the political empowerment of young people and youth employment within the current complexities of development debates, the global economic recession, rising challenges from climate change, and the pressing need for a transition to energy efficiency and a sustainable economy. Key research questions need to address the competences and leadership potential of young people to participate in decisionmaking on sustainability issues; the ways in which changing environmental circumstances affect the working conditions of young workers; whether job creation in emerging sectors can address the rising problem of youth unemployment; whether students across diverse sectors and disciplines have adequate skills to adapt and manage a transforming lifestyle and working environment, and whether gender balance is being considered and addressed in policy consultations and the transition to green jobs (ILO 2012; Stevens 2009). Answering these questions requires multiple systematic studies using quantitative and qualitative tools and across different countries and youth populations.

\section{References}

Baethge M., Achtenhagen F., Arends L., Babic E., Baethge-Kinsky V., Weber S. (2006), PISA-VET. A feasibility-study, Franz Steiner Verlag, Stuttgart.

Barnett R. (2000), Supercomplexity and the curriculum, „Studies in Higher Education”, vol. 25 no. 3 , pp. 255-265.

Barth M. (2013), Many roads lead to sustainability. A process-oriented analysis of change in higher education, „International Journal of Sustainability in Higher Education”, vol. 14 no. 2, pp. 160-175.

Barth M., Godemann J., Rieckmann M., Stoltenberg U. (2007), Developing key competencies for sustainable development in higher education, „International Journal of Sustainability in Higher Education", vol. 8 no. 4, pp. 416-430.

Bopape J. (2009), Professional development of teachers for effective environmental education, doctoral dissertation, University of South Africa.

Brundiers K., Wiek A., Redman C.L. (2010), Real-world learning opportunities in sustainability. From classroom into the real world, „International Journal of Sustainability in Higher Education”, vol. 11 no. 4, pp. 308-324. 


\section{THE ROLE OF HIGHER EDUCATION IN PREPARING YOUTH TO MANAGE ...}

Burandt S., Barth M. (2010), Learning settings to face climate change, „Journal of Cleaner Production”, vol. 18 no. 7, pp. 659-665.

Cebrián G., Grace M., Humphris D. (2015), Academic staff engagement in education for sustainable development, „Journal of Cleaner Production”, vol. 106, pp. 79-86.

Cebrián G., Junyent M. (2015), Competencies in education for sustainable development. Exploring the student teachers” views, „Sustainability”, vol. 7 no. 3, pp. 2768-2786.

Cortese A.D. (2003), The critical role of higher education in creating a sustainable future, „Planning for Higher Education", vol. 31 no. 3, pp. 15-22.

De Haan G. (2006), The BLK "21” programme in Germany. A "Gestaltungskompetenz"-based model for education for sustainable development, „Environmental Education Research”, vol. 12, pp. 19-32.

Di Giulio A., Defila R. (2017), Enabling university educators to equip students with inter-and transdisciplinary competencies, „International Journal of Sustainability in Higher Education”, vol. 18 no. 5, pp. 630-647.

Disterheft A., Caeiro S., Azeiteiro U.M., Leal Filho W. (2015), Sustainable universities - a study of critical success factors for participatory approaches, „Journal of Cleaner Production”, vol. 106, pp. 1121.

European Commission (2009), New skills for new jobs. Anticipating and matching labour market and skills needs, Directorate-General for Education and Culture, Luxembourg, http://bibliotekakrk.ibe.edu.pl/opac_css/doc_num.php?explnum_id=156 [21.09.2019].

Fahey S. (2012), Curriculum change and climate change. Inside outside pressures in higher education, „Journal of Curriculum Studies”, vol. 44 no. 5, pp. 703-722.

Fritze J., Blashki G., Burke S., Wiseman J. (2008), Hope, despair, and transformation. Climate change and the promotion of mental health and well-being, „International Journal of Mental Health Systems”, vol. 13 no. 2, https://ijmhs.biomedcentral.com/track/pdf/10.1186/1752-4458-2-13 [21.09.2019].

Hoover E., Harder M.K. (2015), What lies beneath the surface? The hidden complexities of organizational change for sustainability in higher education, „Journal of Cleaner Production”, vol. 106, pp. $175-188$.

ILO (2012), Working towards sustainable development. Opportunities for decent work and social inclusion in a green economy. A Report by the Green Jobs Initiative, International Labour Organization, Geneva.

Lambrechts W., Gelderman C.J., Semeijn J., Verhoeven E. (2019), The role of individual sustainability competences in eco-design building projects, „Journal of Cleaner Production”, vol. 208, pp. 1631-1641.

Lambrechts W., Ghijsen P.W.T., Jacques A., Walravens H., Van Liedekerke L., Van Petegem P. (2018), Sustainability segmentation of business students. Toward self-regulated development of critical and interpretational competences in a post-truth era, „Journal of Cleaner Production”, vol. 202, pp. 561-570. 


\section{Mona BETOUR EL ZOGHBI, Wim LAMBRECHTS}

Lambrechts W., Verhulst E., Rymenams S. (2017), Professional development of sustainability competences in higher education. The role of empowerment, „International Journal of Sustainability in Higher Education", vol. 18 no. 5, pp. 697-714.

Lambrechts W., Van Petegem P. (2016), The interrelations between competences for sustainable development and research competences, „International Journal of Sustainability in Higher Education”, vol. 17 no. 6 , pp. 776-795.

Lambrechts W., Van Liedekerke L., Rymenams S. (2015), Connecting sustainability initiatives with efficiency measures. Aan opportunity for business schools, „Central and Eastern European Journal of Management and Economics", vol. 3 no. 2, pp. 161-173.

Lambrechts W., Mulà I., Ceulemans K., Molderez I., Gaeremynck V. (2013), The integration of competences for sustainable development in higher education. An analysis of bachelors programs in management, ,Journal of Cleaner Production”, vol. 48, pp. 65-73.

Leal Filho W. (2011), About the role of universities and their contribution to sustainable development, „Higher Education Policy”, vol. 24 no. 4, pp. 427-438.

Levin K., Cashore B., Bernstein S., Auld G. (2012), Overcoming the tragedy of super wicked problems. Constraining our future selves to ameliorate global climate change, „Policy Sciences”, vol. 45 no. 2, pp. 123-152.

Lotz-Sisitka H. (2009), Insights from an environmental education research programme in South Africa, in: Learning/work. Turning work and lifelong learning inside out, eds. Cooper L., Walters S., Human Sciences Research Council (HSRC) Press, Cape Town.

Lotz-Sisitka H. (2002), Weaving cloths. Research design in contexts of transformation, „Canadian Journal of Environmental Education”, vol. 7 no. 2, pp. 101-124.

Lozano R., Lukman R., Lozano F.J., Huisingh D., Lambrechts W. (2013), Declarations for sustainability in higher education. Becoming better leaders, through addressing the university system, ,Journal of Cleaner Production”, vol. 48, pp. 10-19.

Lozano R., Ceulemans K., Alonso-Almeida M., Huisingh D., Lozano F.J., Waas T., Lambrechts W., Lukman R., Hugé J. (2015), A review of commitment and implementation of sustainable development in higher education: results from a worldwide survey, „Journal of Cleaner Production”, vol. 108, pp. 118.

Madzwamuse M. (2010), Climate change vulnerability and adaptation preparedness in South Africa, Heinrich Böll Stiftung Southern Africa, Cape Town.

Matthews J., Waterman P. (2010), Sustainable literacy and climate change. Engagement, partnerships, projects, in: Universities and climate change. Introducing climate change at university programmes, ed. Filho W.L., Springer, pp. 83-88.

McKeowen R., Hopkins C. (2010), Rethinking climate change education, „Green Teacher”, vol. 89, pp. $17-21$.

Moodley K. (2010), Education for sustainable development. Local and non-governmental organizations in Gauteng - Practices. A research r 


\section{THE ROLE OF HIGHER EDUCATION IN PREPARING YOUTH TO MANAGE ...}

https://pdfs.semanticscholar.org/18af/104f9971e39cbe8d56f6143d561b7db69840.pdf?_ga=2.82279710 .985436398.1569069474-2050523378.1569069474 [21.09.2019].

Mula I., Tilbury D., Ryan A., Mader M., Dlouha J., Mader C., Benayas J., Dlouhý J., Alba D. (2017), Catalysing change in higher education for sustainable development. A review of professional development initiatives for university educators, „International Journal of Sustainability in Higher Education”, vol. 18 no. 5, pp. 798-820.

Nyoni D. (2009), Youth participation in addressing global challenges. The promise of the future, in: Young people, education, and sustainable development. Exploring principles, perspectives, and praxis, eds. Corcoran P.B., Osano P., Wageningen Academic Publishers, The Netherlands.

Orr D. (2004), Earth in mind. On education, environment, and the human prospect, Island Press, Washington.

PBL (2011), Exploration of pathways towards a clean economy by 2050. How to realise a climate-neutral Netherlands, Netherlands Environmental Assessment Agency, The Hague.

Ploum L., Blok V., Lans T., Omta O. (2018), Toward a validated competence framework for sustainable entrepreneurship, „Organization \& Environment”, vol. 31 no. 2, pp. 113-132.

Rieckmann M. (2012), Future-oriented higher education. Which key competencies should be fostered through university teaching and learning?, „Futures”, vol. 44 no. 2, pp. 127-135.

Rychen D.S., Salganik L.K. (2003), Key competencies for a successful life and a well-functioning society, Hogrefe \& Huber, Boston.

Salgado Perez F., Abbott D., Wilson G. (2018), Dimensions of professional competences for interventions towards sustainability, „Sustainability Science”, vol. 13 no. 1, pp. 163-177.

Sterling S. (2008), Sustainable education - towards a deep learning response to unsustainability, „Policy \& Practice. A Development Education Review", vol. 6, pp. 63-68.

Stewart M. (2010), Transforming higher education: a practical plan for integrating sustainability education into the student experience, „Journal of Sustainability Education”, vol. 1, http://www.jsedimensions.org/wordpress/wp-content/uploads/2010/05/Stewart2010.pdf [21.09.2019].

Stevens C. (2009), Green jobs and women workers. Employment, equity, equality draft report, Sustainlabour, Madrid.

Tauritz R. (2012), How to handle knowledge uncertainty. Learning and teaching in times of accelerating change, in: Learning for Sustainability in Times of Accelerating Change, eds. Wals A.E.J., Corcoran P.B., Wageningen Academic Pub., The Netherlands, pp. 299-316.

Tejedor G., Segalàs J., Rosas-Casals M. (2018), Transdisciplinarity in higher education for sustainability. How discourses are approached in engineering education, „Journal of Cleaner Production”, vol. 175, pp. 29-37.

Tilbury D. (2011), Are we learning to change? Mapping global progress in education for sustainable development in the lead up to 'Rio Plus 20', „Global Environmental Research”, vol. 14 no. 2, pp. 101107. 


\section{Mona BETOUR EL ZOGHBI, Wim LAMBRECHTS}

UNDESA (2010), World Youth Report. Youth and climate change, United Nations Department of Economic and Social Affairs, New York.

Van Heeswijk J. (2009), Young and sustainable. Young people, sustainable development, and education, Hiteq, The Netherlands.

Vaughan A. (2019), Climate protest goes global, „New Scientist”, vol. 241 no. 3221, p. 7.

Verhulst E., Lambrechts W. (2015), Fostering the incorporation of sustainable development in higher education. Lessons learned from a change management perspective, „Journal of Cleaner Production”, vol. 106, pp. 189-204.

Wals, A. E. (2014), Sustainability in higher education in the context of the UN DESD: a review of learning and institutionalization processes. ,Journal of Cleaner Production, 62, 8-15.

Wiek A., Withycombe L., Redman C. (2011), Key competencies in sustainability. A reference framework for academic program development, „Integrated Research System for Sustainability Science", vol. 6 no. 2, pp. 203-218.

Willis J. (2007), Foundations of qualitative research. Interpretive and critical approaches, Sage, London. 